\title{
Agnieszka Gawron, Macierzyństwo. Współczesna literatura, kultura, etyka, Wydawnictwo Uniwersytetu Łódzkiego, Łódź 2016, ss. 337
}

Monografia Agnieszki Gawron Macierzyństwo. Wspótczesna literatura, kultura, etyka, będąc pierwszą w Polsce, pisaną z perspektywy literaturoznawstwa, całościową próbą wypełnienia badawczej luki w studiach nad macierzyństwem, przysporzyć może odbiorcy licznych satysfakcji - z poznawczą, rzecz jasna, na czele. Ta zaś obejmuje zarówno przejrzyście sproblematyzowany aspekt ewolucyjny motherhood studies (trwających na Zachodzie od blisko czterdziestu lat i funkcjonujących w ramach struktur akademickich, a w Polsce reprezentowanych głównie pracami o nachyleniu socjologicznym i pedagogicznym), jak wartościowe metodologicznie, obudowane kontekstami wykładnie interpretacyjne tekstów kultury, o których specyfice decyduje podmiotowe ujęcie macierzyństwa.

„Zaczynam od matki” - deklaruje Gawron i stawia w centrum swoich badań narracje matrifokalne, określając tak „teksty, w których podstawowym wyróżnikiem jest dominująca perspektywa narracji matki, a macierzyństwo stanowi najważniejszy/nadrzędny element struktury fabularnej” (s. 15). We Wprowadzeniu do książki autorka jasno określa pobudki i zamierzenia towarzyszące jej badaniom: nie interesują jej wyidealizowane i selektywne reprezentacje macierzyństwa, które dotąd zdają się dominujące choćby w antologiach czy mini-przekrojach, chce natomiast oddać w analizach artefaktów wielowarstwowość fenomenu (wraz z tematami i problemami dotychczas ukrywanymi bądź pomijanymi), którego złożoność najbardziej wiarygodnie może uobecniać, kreować właśnie matka. Zgadzając się z Mielle Chandler, iż to słowo jest najpełniej zrozumiałe w aspekcie czasownikowym, Gawron, jako badaczka matrifocal narratives i tak jak interpretowane przez nią autorki, obiera pozycję, z której się pisze i w jakiej się na co dzień funkcjonuje. Tym samym macierzyńską praktykę codzienności jest w stanie reprezentować w przekroju poznawczym, emancypacyjnym i twórczym. 
Dla badaczki pierwszoosobowych narracji matek ostatnie dwudziestolecia (w literaturze polskiej mniej więcej od późnych lat 90.) to czas ekspansji tego rodzaju wypowiedzi literackich, przynależących zresztą do różnych obszarów kultury wysokiej i popularnej, reprezentujących rozmaite jej postacie (powieści, wiersze, eseje, wspomnienia, komiksy, felietony, personal criticism, nawet piosenki i zapisy blogowe). Wybór analizowanych w książce tekstów miał w intencji autorki unaoczniać dynamikę życia literackiego przełomu wieków, kiedy wzrosła intensywność matrifokalnych artykulacji, traktowanych w kategoriach praktyki filozoficznej, intelektualnej i autobiograficznej zarazem. Prezentując zatem tak rozwój, jak idiomatyczność macierzyńskich artefaktów pierwszoosobowych, Agnieszka Gawron bada kulturowe matrifocal narrative w opcji dyskursywnego (tekstowego) udostępniania żywego doświadczenia w wielu jego odsłonach — zawsze tych, w których matki tworzą, piszą, a nie „są pisane” przez innych. Analizując formalną i estetyczną różnorodność ich wypowiedzi, problematykę, wątki i tematy, wokół których jest zorganizowana, badaczka eksponuje wielokrotnie to, co skupia się w owych narracjach jak w soczewce: współczesne przemiany stereotypów, wzorców macierzyńskich, skostniałych w długim trwaniu tradycji wyobrażeń i konstruktów kulturowych. Pyta o „miejsce macierzyńskiego pisania w kanonie tematów i form literackich oraz relacje pomiędzy doświadczeniem egzystencjalnym a aktywnością twórczą kobiet" (s. 17). Pyta i — w moim odbiorze — satysfakcjonująco odpowiada. Jej wywód jest przemyślany, klarowny, pieczołowicie obudowany interdyscyplinarnym stanem badań, wyposażony w liczne egzemplifikacje artystyczne, zrealizowany w formule tyleż precyzyjnej, co niestroniącej od eseistycznej swobody. Dzięki takim walorom otwiera się nie tylko na czytelnika stricte profesjonalnego, co wobec rangi centralnego dla książki problemu: maternalnego zwrotu w kulturze współczesnej, wydaje się cenne.

Monografię Agnieszki Gawron postrzegam jako książkę ważną, bardzo potrzebną, porządkującą w wyłonionym paradygmacie i wyraziście problematyzującą rozproszone głosy oraz glossy, które ukazują rozległą panoramę zagadnień społeczno-kulturowych, literackich, genderowych wiążących się w refleksji humanistycznej z macierzyństwem. W ich przekroju dopiero widać, w jakim stopniu opracowanie to stanowi swoistą summę dotychczasowych uzgodnień i jak dalece poza nie wykracza.

Eksponując zwrot maternalny, jaki dokonał/dokonuje się od końca ubiegłego wieku w literaturze i krytyce, autorka oświetla go przy użyciu ruchomych i wielorakich kontekstów. Nie ogranicza się do rejestracji zjawisk wskazujących na ów zwrot, lecz podejmuje próbę pogłębionego ich usystematyzowania oraz opisu. Na poziomie analityczno-interpretacyjnym jest on innowacyjny. Umiejętnie funkcjonalizowane, wciąż obecne zaplecze teoretyczne pozwala autorce wydobywać nieoczywiste, a rudymentarnie istotne dla badanego zagadnienia sensy utworów, zwłaszcza rodzimych (ale nie tylko), oraz rozmaite odcienie ich konstrukcji. Stosując aparaturę terminologiczną, która wyczula na uzgodnienia wypracowane poza samym literaturoznawstwem, (choćby szeroko pojętym), Gawron utwierdza charakter dyskursu w odniesieniu do macierzyństwa jako zagadnienia wywalczającego sobie coraz większe znaczenie, zwłaszcza z perspektywy mówiących/piszących kobiet, matek, które przestają być „mówione” i „opisywane”, a odzyskując głos, stały się pierwszoosobowo piszącymi i mówiącymi. Wnosi na grunt polski szereg narzędzi i poręcznych metafor na prawach terminów, buduje solidną bazę, której walory poznawcze będą służyły także tekstom, jakie tutaj nie stały się przedmiotem analizy - i tym, które dopiero powstaną. 
Nie było dotąd na gruncie polskim tak komplementarnej rozprawy, która eksponowałaby w wielu przekrojach fenomen macierzyństwa we współczesnych artefaktach i refleksji metodologicznej. Sama refleksja jest już wszak rozległa, tak w skali międzyobszarowej teorii, jak w zakresie twórczych uobecnień. Niemniej dotychczas ani w ten sposób nie zestawiono, nie zhierarchizowano, ani nie prześwietlono artykulacji macierzyństwa pod kątem wyłonienia wielu, wzajemnie się przenikających punktów widzenia. Przekonują o tym w książce Gawron m.in. liczne, skompletowane w obszernej bibliografii prace krytyczne z zakresu literaturoznawstwa, studiów genderowych, filozofii, etyki, kulturoznawstwa, pedagogiki, także rozprawy metodologiczne, rozmowy, eseje, wypowiedzi o nachyleniu socjologicznym, politycznym, psychologicznym, kompetentnie i „z nerwem” referowane przez badaczkę w toku wywodu. Teksty to w dużej mierze anglojęzyczne, podobnie jak wiele znajduje się w opracowaniu przykładów literackich realizacji dyskursu maternalnego, które pochodzą z innych niż polska literatur. Monografia Agnieszki Gawron jest bowiem z ducha i praktyki komparatystyczna, co zapewne wynika pospołu tak z dotychczas dostępnych źródeł literackich i przedmiotowych w zakresie analizowanego zjawiska (pierwszoosobowych narracji macierzyńskich oraz odnośnych komentarzy krytycznych), jak z przekonania o transgranicznym sensie badań naukowych, które pozwalają uchwycić i naświetlić złożoność jego problematyki $\mathrm{z}$ wielu stron.

Dużą wartością monografii Agnieszki Gawron na polskim gruncie jest przyjęta tu wyrazista optyka analityczno-interpretacyjna. Pozostaje ona konsekwentnie scentralizowana na zwrocie maternalnym, zarówno w zarysie diachronicznym, jak przy prezentowaniu istotnych uzgodnień teoretyczno-pojęciowych. Także podczas stosowania wypreparowanych myśli i narzędzi w wykładniach analitycznych wybranych artefaktów: prozatorskich, poetyckich, plastycznych, filmowych, blogowych - o tej rozmaitości była mowa. Za każdym razem celnie sfunkcjonalizowane instrumentarium, które badaczka ma na podorędziu, służy wyeksponowaniu specyfiki oraz rangi narracji matrifokalnych. I mam na myśli nie tylko wartość artystyczną, której upatrywać można w wielotorowym poszukiwaniu nowej artykulacji, mediatyzującej pomiędzy porządkami symbolicznym i semiotycznym dla wyrażania specyfiki akurat tego konkretnego, macierzyńskiego doświadczania kobiecych ról (lub niedoświadczania - co wszakoż jest opatrzone szeregiem obciążeń i dylematów idących z kulturowych i instytucjonalnych uwikłań), sytuacji egzystencjalno-fizjologiczno-psychologicznych, także wpisanych w nie rozmaitych opresji. Ranga tych narracji sięga horyzontów zasadniczych, by tak rzec: po ludzku przejmujących i wciąż nieoswojonych, a odsłaniane przez badaczkę ich warstwy uświadamiają głębię zjawiska. Odwiecznego jak macierzyństwo - i jak mówienie/ pisanie o nim. Do niedawna było figurowane w wielowiekowych narracjach patriarchalnych, teraz ich barierę, wciąż trudną do zniesienia, zaczęły równoważyć pierwszoosobowe głosy kobiece - w istocie najbardziej miarodajne w zakresie artykulacji fenomenu.

Agnieszka Gawron, sięgając w interpretacjach narracji matrifokalnych po aparaturę pojęciową i optykę kilku dziedzin nauki, uruchamiając w komentarzach rozległe konteksty, przekonująco demonstruje konieczne spotkanie, przenikanie się i uzupełnianie wielogłosu studiów nad macierzyństwem w spojrzeniu na zjawisko wciąż świeże (przypomnę: liczące, pominąwszy antecedensy, lat około 40, w Polsce zaś nasilające się od lat 90.). Decyzje badawcze, miejsce, z którego zabiera głos - zostały jasno określone we wstępnych partiach monografii. Deklaracja dotyczy wyboru lektur i gestów interpretatorki. Wkraczając na ten obszar, 
niewyeksploatowany przecież nie tylko na gruncie polskim, Gawron wybiera „empatyczny typ lektury, zakładający uwrażliwienie na to, co jednostkowe, co dane bezpośrednio, ale też nieobecne lub wymagające uobecnienia” (s. 13). Dodaje do tego poręczenie biografii interpretatora jako „ważny i wzmacniający perspektywę badawczą element naukowego dyskursu, aczkolwiek nie bezwzględnie kategoryczny” (tamże).

Rozmaite są stanowiska wobec badawczych wyznań tak śmiałych, jak na przykład to sformułowane przez autorkę we Wprowadzeniu: „Choć nigdy nie wypowiadałam się w kwestiach naukowych »jako matka«, pracę i macierzyństwo trudno jest od siebie odseparować [...]. W tym projekcie dyskurs macierzyński i akademicki otwarcie się spotykają. Wierzę, że sprzęgnięcie tego, co prywatne i publiczne, osobiste i instytucjonalne może być twórcze i produktywne, podobnie jak związki macierzyństwa i literatury” (s. 19). Mówiąc z przekonaniem „tak” wyrażonemu w ten sposób poglądowi, nie mogę się powstrzymać przed wydobyciem modalności z powyższej deklaracji — modalności pozornie niewinnej, stanowiącej jednak języczek u wagi. Bo w istocie koincydencja osobistego zaangażowania, podmiotowej sygnatury badacza - „m oż e być” cenna, okazać się skuteczniejsza naukowo od chłodnego obiektywizmu lub niedostępności pewnych doświadczeń (bo uwrażliwia na niuanse przetestowane własną biografią czy prywatne niepokoje) - ale n i e musi. Niosąc oczywiste zagrożenia dla pożądanego jednak w naukowym dyskursie dystansu, kładzie na szalę pytania o możliwość współgrania intelektu oraz intuicji badacza, o — by tak rzec — dopuszczalny w refleksji naukowej poziom pierwiastka subiektywnego.

W moim odbiorze Agnieszka Gawron uniknęła pułapek emotywnej selekcji materiału (a także samych lektur), stawiając na to, co najlepsze: zaangażowanie, pasję, trzeźwy, rzeczowy krytycyzm do treści tkwiących w artefaktach, w teoriach wokół macierzyństwa, w analizach adekwatnych zjawisk socjologicznych, politycznych. I nie w tym rzecz nawet, że w charakterze kobiecego czytania/pisania tkwi mandat do sankcjonowania rezultatów, także odnośnych badań naukowych, podmiotową sygnaturą. W książce Gawron erudycja i żywe doświadczenie stanowią wzajem dla siebie weryfikatory proponowanych tez, uzgodnień, wysuwanych hipotez interpretacyjnych, mnie z reguły przekonujących. Bardziej — przy wykładniach prozy, mniej - przy poezji, kiedy czasami umykały interesujące rozwiązania konstrukcyjne przytaczanych wyimków, polisemia metafor, kapitalne gry lingwistyczne, ustępując miejsca krótkiemu, puentującemu komentarzowi, który „co” powiedziane stawiał nad „jak” wyrażone, pozostawiając momentami niedosyt analityczny. Co zaznaczam także z pierwszoosobową sygnaturą recenzentki, nie tyle zawiedzionej czy niezgadzającej się z przedstawionymi mikroanalizami poetologicznymi (zostały inteligentnie włączone w logikę dyskursu), a raczej upominającej się o większą precyzję wobec owego „jak”. Wówczas metaforyczne „krótkie spięcia sensów” tym pełniej mogłyby ujawnić także matrifokalne pokłady wytwarzanych znaczeń. Sądzę, że szczególnie w metaforach językowych, niejednokrotnie zaś (jak w poezji Joanny Mueller na przykład) pseudoetymologie, rytmy, rewelatorskie konstrukcje foniczne, neologizmy, które pozostają niezwykle bliskie semiotycznemu trybowi „nieustannej produktywności znaczeniowej” (J. Kristeva) i zwracają się ku temu, co poprzedzało akt symbolizacji, co odwołuje się do sfery zmysłowo-cielesnej.

Omawiana monografia składa się z trzech części podzielonych na liczne rozdziały, których tytuły stają się czytelnymi wektorami ułatwiającymi nawigację wśród wielości zagadnień, utworów, aspektów objętych refleksją badawczą. Tych jest doprawdy wiele. Tytuły są różnorodne, niektóre rzeczowo referencyjne (Dyskurs maternalny w Polsce, Literatura wobec 
stereotypu macierzyństwa, Macierzyństwo w dyskursie feministycznym), inne - uwodzące literacką frazą, prowokujące ciekawość („Sztuka prania pieluch”- matki negocjatorki w sztuce wspótczesnej, „Wracam, bo... zniknętam” - aporie macierzyńskiej podmiotowości, „Gdy rozum śpi - rodzq sie matki" - literacki wizerunek dzieciobójczyni...). Różnorodność i stylistyka tytułów zapowiadają to, co okazuje się stałym atrybutem wywodu Agnieszki Gawron. Jest nim umiejętne wyważenie proporcji pomiędzy dyskursem stricte specjalistycznym, zadość czyniącym rygorom akademickim, nakierowanym na dość wąskie jednak grono odbiorców, a eseistycznym otwarciem na czytelnika spoza akademii. Być może zainteresowanego zagadnieniem, poszukującego miarodajnego wykładu o jego wielowarstwowości, o rozwoju kulturowej świadomości na temat macierzyństwa, o emancypowaniu się kobiecego głosu, także o egzystencjalnych, psychologicznych, instytucjonalnych opresjach, które są wpisane w role kobiece, z wyboru lub nie, łączące się z macierzyństwem.

Układ kolejnych części książki dobrze prowadzi od perspektywy ogólnej (prezentowanej wnikliwie, bez skrótów) do interpretacji idiomatycznych propozycji literackich, artystycznych. One, rzutowane na wcześniej przygotowane tło, tym czytelniej ukazują swoją specyfikę w komentarzach badaczki. Rozpoczynając od rekonstrukcji teorii i stanu badań nad macierzyństwem, zarysu dziejów refleksji, jej uwarunkowań w kulturze i ramach instytucjonalnych, przechodzi autorka ku wyrazistszemu skupieniu na przekrojach problemowych macierzyństwa odbitych w narracjach prozatorskich i twórczości poetyckiej (traktowanej tu jako istotny element ewolucji realizacji matrifokalnych). Zaprezentowane zostało zróżnicowanie genologiczne (zarazem: bogactwo) kreacji i narracji macierzyńskich, w tym wspomnień matek, do których — zasadnie - Gawron przywiązuje dużą rolę.

Choć we wszystkich częściach książki obcuje się z wywodem komplementarnie zespalającym warstwy refleksji teoretycznej z interpretacją artefaktów, coraz wyraźniej wykład zmierza w kierunku literackiego mikrokosmosu wybranych narracji matrifokalnych, ku analizom poszczególnych utworów. Bardzo ładnie ukazują zresztą te wzajemne powinowactwa, przemyślaną kolejność części, ich tytuły. Zestawione, układają się w figurę anadiplozy. Drugie słowo formuły tytułowej każdej z części rozprawy staje się słowem pierwszym części kolejnej: Teorie i problemy; Problemy i teksty; Teksty i lektury. I w istocie sugestia owej płynności podchwytywania uzgodnień nie jest nadużyta wobec zawartości integralnych partii pracy. Informuje, adekwatnie wobec treści, o specyficznym stopniowaniu emotywności, pierwiastka subiektywnego - tak w geście selekcji przywoływanych koncepcji i utworów, jak podczas ich omawiania. Lektury mają prawo być bardziej subiektywne niż sprawozdanie z „twardych” uzgodnień teoretyczno-krytycznych. Ten porządek został w książce wyeksponowany, co zarazem jest swoistą asekuracją — zabezpiecza interpretatorkę, która pośrednio powiada: moja lekcja tekstu nie rości sobie ambicji do koniecznie obiektywnej racji; nie ustanawiam apodyktycznie pola lektury, ale i zaznaczam własne prawo do jej wykładni.

Do opublikowanej przed czterema laty monografii Agnieszki Gawron Macierzyństwo. Wspótczesna literatura, kultura, etyka powróciłam z niekłamaną satysfakcją. Kolejna lektura utwierdziła pierwsze wrażenie: to książka o cennych walorach poznawczych, sprawna i barwna w warstwie analityczno-interpretacyjnej, innowacyjna w zakresie panoramicznego, a zarazem zniuansowanego przedstawienia fenomenu narracji matrifokalnych oraz szeregu rudymentarnie ważnych zagadnień wiążących się z macierzyństwem. Jej interdyscyplinarny i komparatystyczny charakter sprawia, że ma szansę stać się lekturą obowiązkową nie tylko dla literaturoznawców, odbiorców zainteresowanych studiami genderowymi, humanistów 
i specjalistów w obszarze nauk społecznych, ale też zaistnieć w przestrzeni pozauniwersyteckiej. Poczytuję to za walor, nie zaś symptom osłabienia specjalistyczności czy profesjonalnej hermetyczności dyskursu i metod autorki. Że (raczej) nie jestem w błędzie, można się zapewne łatwo przekonać, konfrontując wyrażone w recenzji opinie z tą monografią, doprawdy wartą przestudiowania.

Danuta Opacka-Walasek

(iD https://orcid.org/0000-0001-9104-0590 